\title{
Environmental management legislation and competitiveness: case studies from Brazil, Germany, Italy and the United Kingdom
}

\begin{abstract}
Globally, consumption and production levels have risen markedly in recent decades. These rises have led to costs/externalities (e.g. pollution and production of waste). Environmental regulations are employed as a means of controlling and managing these externalities. Using Germany, Italy, Brazil and the UK as case study countries, this study sought to examine the manner in which environmental regulations impacted upon business competitiveness within selected sectors. The results suggest that environmental regulations did impact upon competitiveness (as measured by levels of innovation). However, this influence varied within and between countries, and sectors, with for example, a higher impact in Germany, and within the manufacturing and construction sectors. The key implications for these findings are also discussed.
\end{abstract}

Key words: Business competitiveness, Environmental legislation, Sustainability, Greenhouse gas emissions, Innovation 


\section{Introduction}

Globally, notwithstanding the economic shocks and risks that have prevailed since 2008, consumption of resources is increasing and this trend is generally predicted to continue (World Bank, 2016; Statista, 2017). This increase in the production and consumption of resources results in costs (i.e. externalities such as the production of waste, pollution and loss of livelihoods). These externalities represent a challenge to achieving a more sustainable economic growth. This is particularly true in the case of rapidly developing countries such as the BRICs (Brazil, Russia, India and China). Indeed, UNEP (2017) argues that the world cannot achieve sustainable economic growth without significant innovation in both supply (production) and demand (consumption). Through the use of environmental regulations (e.g. taxes), governments aim to 'correct' the discrepancy by internalising the costs of the externalities, in order to better reflect a truer price for the resources (Colyer, 2004). The policies and actions of governments do, however, vary. Generally, developing countries tend to use more stringent policies as compared to developing countries (EEA, 2015; EC, 2016). For example, issues around climate change have received significant attention from several sectors in Europe, while in Brazil even though it is gaining attention, the issue is not a priority for the Government or society (Araújo et al., 2015).

Using selected countries from the European Union (EU), namely the UK, Germany and Italy, as well as Brazil, this study aimed to examine the nature of the relationship between environmental regulations and competitiveness at the country level. These three EU countries possess divergent economies, but within a similar overarching environmental regulatory context, albeit with varying implementation and enforcement regimes. For example, implementation regimes in Germany are one of the strongest, while in Italy they are less so. Brazil, as one of the BRIC countries provides the perspective from one of the world's emerging 
economies. Thus examining countries from the EU offers a range of contexts and perspectives as it relates to business competitiveness and the environment.

\section{Environmental regulation in the case study countries}

Following on from the first Environment Action Programme in 1973 (the current version is 2015 - 2020), and since the 1987 Single European Act (SEA) (the Maastricht Treaty), environmental protection has been enshrined into European policies. There are a number of pieces of legislation in the form of Directives that cover various aspects of the environment, including the Waste Framework Directive and the Water Framework Directive and the EU Sustainable Development Strategy.

Environmental regulation in Brazil has increased significantly in the past 50 years (Gradient Corp, nd). For example, the Conselho Nacional do Meio Ambiente (CONAMA), was created in 1981 to develop federal environmental policy for the country. In 1968, there was the formation of Centro Tecnológico de Saneamento Básico (CETESB) to improve environmental sanitation in Sao Paulo. The CETESB was later renamed the Companhia Ambiental do Estado de São Paulo, aimed at regulating and licensing pollution-generating activities, and covering soil, ground water and air. Two examples, of regulations promulgated by CONAMA include Resolution 430 in 2011, which covers standards for effluent discharge, including standards for VOCs and metals in industrial waste waters, and Resolution 420, in 2009, which covers the management of contaminated sites in Brazil.

\section{Competitive advantage and environmental regulation}

There was an initial wave of environmental regulations in the $1960 \mathrm{~s}$ and $70 \mathrm{~s}$, coming out of various pollution incidents and growing calls for enhanced governance measures (e.g. Carson, 1962). According to various authors (e.g. Meyer, 1992; Metcalfe, 2002), the regulations of the 
1970s did negatively impact on global economies. This was largely because they had been unplanned, required a significant capital outlay and were primarily focused on 'end of pipe' control systems (e.g. air pollution scrubbers on chimneys and catalytic convertors on cars, which added costs, but did not necessarily improve the product). However, Metcalfe (2002) notes that since then, the link between regulation and negative economic impacts has become at best minimal, and is largely due to perceptions rather than reality.

Porter (1998) argues that productivity at the national level is dependent on a range of 'factor endowments' that a country might have including land, natural resources, labour and the size of the population. However, competitive advantage could be gained through the availability of capital, the skills and competencies of the workforce, and the implementation of commercial technologies, government support and culture. These factors influence:

- the availability of resources and skills

- information that firms use to decide which opportunities to pursue with those resources and skills

- the goals of individuals in companies

- the pressure on companies to innovate and invest.

Levels of competitiveness can vary in two different countries with similar environmental regulations (Colyer, 2004). Difference in implementation, though difficult to measure, can also lead to differences in competitiveness (Jaffe et al., 1995). The differences may be due to the efficiency of the regulatory regimes or the existence of subsidies, tax write-offs or other government incentives. For example, the cost sharing for soil conservation in the USA through the Natural Resources Conservation Service, of the US Department of Agriculture, during the 1940s, 50s and 60s promoted soil conservation. However, it also led to competitive advantage 
for farmers due to the green subsidy payments and the technical assistance provided to farmers. These benefits enabled the farmers to charge lower prices, and boost productivity, thereby making them more competitive.

Most of the previous work on environmental regulations and competitiveness at the national level, has focused on international trade. According to Colyer (2004), due to the public health and environmental health risks associated with factors such as fertilisers, pesticides, genetically modified organisms (GMOs), and contaminated meat and fish products, agriculture and agricultural products (e.g. meats), have for many years been a key focus for environmental regulation. A number of studies (e.g. Porter and van der Linde, 1995a; Andersen et al., 2007; De Santis, 2012) suggest that environmental regulation can have a significant negative affect on trade, particularly at the sector level as it is the heavy industry that produces goods and intermediary products for other industries. As it is often larger corporations that are best able to comply, this therefore results in fewer entities and therefore reduced competition. Alternatively, other authors contend that strict environmental regulations do not negatively impact upon international trade and competitiveness (Tobey, 1990; Jaffe et al., 1995; Harris et al., 2002; Arouri et al., 2012). For example, Arouri et al. (2012) argue that other factors such as labour costs have a more significant impact. Specifically for highly polluting sectors, environmental regulations have a significant and positive impact on exports, but not on imports. Similarly, Colyer (2004) notes that non-tariff trade barriers (e.g. import licences, sanitary/phytosanitary provisions, quotas and labelling requirements), can lead to competitive advantage for one country at the expense of another. However, some authors contend that levels of innovation in developed countries can minimise the costs of the environmental regulations (Porter and van de Linde, 2002; Porter and van de Linde, 1995b; Ribaudo et al., 2003). 


\section{Methods}

\subsection{Country and sectoral level quantitative data}

The survey sought to first establish trends in environmental impacts for each of the four countries and then based in part on Jaffe et al. (2005) to evaluate the financial and environmental (and by extension health) costs of these impacts. The costs covered factors such as the compliance costs (i.e. the expenditure required for organisations to adhere to the legislation), and the environmental damage. Greenhouse gas (GHG) emissions were chosen as they provide a holistic measure of environmental pollution, as opposed to the single measures that have been employed in other similar studies (e.g. Etsy and Porter, 2005). In addition, these emissions play a crucial role in resource security and climate change, which were two of the key threats to companies identified at the 2015 Climate Change talks in Paris. These were normalised by inclusion of factors such as population size and the Gross Domestic Product (GDP) of the country, in order to enable comparisons to be made between countries.

Data for expenditure on environmental protection, including pollution abatement, costs and expenditure (PACE) data, were accessed from the Eurostat database (http://ec.europa.eu/eurostat/) for the for the three European case study countries. For Brazil, no reliable data could be found. Thus the country and sector comparisons were made using other factors that were available, as proxies. Data on GDP, as well as on GHG emissions were obtained from the websites of the World Bank (World Bank, 2015), and the Organisation for Economic Cooperation and Development (OECD, 2015a;b).

As data were in some cases not readily available, as employed in a number of previous studies (e.g. Harris et al., 2002; Arouri et al., 2012), proxies were utilised. For example, current expenditure, which represents environmental protection activity was used as a measure of environmental stringency and abatement costs. While data on patents for the development of 
environmental technology patents were used as a proxy for innovation. Data on expenditure, and environmental technology patents were obtained from $\operatorname{OECD}(2015, \mathrm{c}-\mathrm{f})$.

Data were selected based on the most recent year available and then retrospectively for at least 10 years, in order to enable reliability and for trends to be evaluated. All the data on the various websites were in Excel format, enabling the relevant files to be downloaded.

At the sectoral level, based in part on Triesbwetter and Hitchens (2005), a case study approach was employed. An overall evaluation of trends in GHG emissions, at the sector level was first conducted. Based on the availability of the data, the sectors were broken down into three main categories, namely: energy; manufacturing and construction; and other. The development of environmental technologies and patents for 'clean' environmental technologies were utilised as a proxy for innovation within the sectors. Data were only available for the three European countries. The data were sourced from the websites of the World Bank, Eurostat and the OECD.

As the data were normally distributed, Pearson correlations were undertaken to test the nature of the relationships between competitiveness (e.g. the development of technologies) and the selected drivers (e.g. environmental taxes). These relationships were examined for each country.

\subsection{Qualitative sectoral data}

Semi-structured interviews were employed to examine and contextualise the sector data, at an organisational level. The aim was to interview individuals from a range of sectors in each of the case study countries. The sectors surveyed cover services (e.g. retail and hotels), farming, manufacturing, supply chain and waste management and examined existing environmental practices, perceptions about links between environmental regulations and competitiveness. 
Face to face interviews were held in the UK and Italy. Table 1 gives the characteristics of the interviewees.

In Germany and Brazil, interviews were done via email correspondence, facilitated by contacts in those two countries. A total of 15 interviews were conducted with individuals from various sectors in the case study countries as follows: UK (6); Germany (2); Brazil (4); and Italy (3). All interviews were conducted between July - September 2015. Senior managers were targeted within the organisation. The purpose of the survey was explained at the start and (potential) interviewees were provided with the questions, beforehand. They were also given the option to participate or not. Given the busy schedules of the interviewees, the interviews typically lasted for no more than about 20 - 30 minutes. Given the reticence of some potential participants, only written rather than audio recordings were conducted. The questions aimed to understand the environmental practices and strategies (e.g. if they used supply chain management or resource conservation) of the organisation, whether they had an environmental policy and the rational for this, and their perceptions of environmental regulations and their impacts on their organisation. Whether they possessed an environmental policy and their practices were used as a proxy for organisational strategy.

Based on Flick (1998), the transcripts of the interviews were read and then analysed by identifying first the open codes and finally the selective codes. These selective codes then served as the key themes of the interviews.

TABLE 1 HERE 


\section{Results}

\subsection{Country level impacts}

Per capita expenditure (\% of GDP), increased in each of the three case study EU countries, during the period of study (Fig. 1). This was particularly so in the cases of UK and Italy, which were both above the average EU28 spend. Indeed, the UK spent around $€ 113.75$ (£81.90) above the EU 28 average since 2006, while Italy spent approximately $€ 58.95$ ( $£ 42.44$ ), over the average, since 2003 .

\section{FIG. 1 HERE}

Apart from on a per capita basis, expenditure can also be examined as a percentage of overall investment in environmental protection (e.g. pollution abatement technologies). Fig. 2 illustrates that while investment in Germany and the UK has generally increased, that for Italy has fallen (N.B. there were no data for 2012). Thus, even though per capita spend in Italy was 'high', overall, it is in the Germany and the UK that the highest overall investment were made in environmental protection.

FIG. 2 HERE

Fig. 3 illustrates that the number of environmental technology patents has generally remained flat across the four countries, between 2000 - 2011. Germany was by far the highest producer of patents amongst the four countries, with Brazil being the lowest.

FIG. 3 HERE

If the development of environmental technologies is looked at as a percentage of all technologies, it can be seen that between 1990 - 2011, Germany has produced more than the 
other three countries (Fig. 4). However, the development of environmental technologies in Brazil has fluctuated significantly.

\section{FIG. 4 HERE}

While GHG emissions in Germany, the UK and Italy generally fell between 1990 - 2012, those in Brazil rose (Fig. 5). Interestingly, Germany, with the highest GDP, also had the highest emissions levels, while Brazil with the lowest GDP, had the lowest emission levels.

\section{FIG. 5 HERE}

\subsection{Sector level impacts}

Table 2 demonstrates that generally as levels of innovation rose (as measured by the development of technology patents and environmental technologies), GHG emissions fell, across key polluting sectors. Rises in environmental taxes also appeared to generally reduce emission levels, particularly in the manufacturing and construction sectors.

\section{TABLE 2 HERE}

\subsubsection{Interviewees' beliefs, perceptions and attitudes}

\subsubsection{Key environmental concerns}

Waste management (e.g. costs for collection of waste) was the key environmental issue noted in the UK. However, in the other countries, the focus was more on air emissions and water pollution. For example, all three of the Brazilian companies stated water and air pollution. Italy2 also mentioned the management of waste water was a key issue, however, they argued that health and safety issues were more important for them.

\subsubsection{Perceptions about a relationship}


UK12 stated that yes there was a link between how they managed their resources and their competitiveness, as they were a "lean company". Saving resources meant "lower costs to us and our traders... and this translates to our customers also". Thus environmental issues were incorporated into the company's policies because the "organisation is founded on conservation. Even our shop counter is made from an old woodworking bench". UK4 also argued, yes, because "the waste management companies keep putting their costs up". Similarly, UK9 stated that "the more considerate we are with what we use or waste, the less our expenditure on resources". Nevertheless, environmental issues were not a strategic focus for any of the three companies. However, environmental management formed a part of the strategic focus for all three of the Brazilian companies. They all had an environmental policy and were strongly of the view that there was a link between being environmentally sustainable and attaining competitive advantage. Indeed, Brazil3 noted that it had:

"implemented a management system with objectives and goals to reduce the consumption of water/paper/energy/residues/ emission of pollutants, to mobilise the supply chain and partners, to raise consciousness of guests, partners, employees, sectorial associations, and to increase the shareholders' satisfaction. As a result, the profitability and the recognition of the hotel has increased".

Similarly, Brazil2 stated that "environmental awareness promotes a culture of "reuse, preserve and waste avoidance". People practice this culture in their activities". The company aimed to minimise use of natural resources, to effectively dispose of its waste and effluent (i.e. waste water), and engage staff in more sustainable practices.

\subsubsection{Is the company currently doing anything green?}

In terms of the employment of green/sustainable approaches, most of the UK interviewees mentioned use of down-stream approaches, particularly recycling. However, those from the 
other countries (e.g. the Brazilian organisations, Germany2 and Italy2 were more focused on their up-stream practices (i.e. supply chain management and waste minimisation).

Brazil2 had developed its own environmental standards. Its corporate policy included environment, and health and safety, and was created "to promote a responsible management of human and natural resources and promote a sustainable growth". Each year during the strategic planning environmental issues were discussed to "define the environmental goals and objectives, aligned with the business goals, environmental policy, corporate directions, governmental regulations, stakeholders' requirements and the factory environmental risks". Brazil1 monitored its suppliers in line with its legal obligations. It also recycled its packaging and reused water, as well as employing ISO 14001, FSSC 22000, OHSAS 18001 and ISO 9001. It actively participated in the management committees of the watersheds of the locations where its plants were installed. Brazil3 used dispensers in the bathrooms with liquid soap and shampoo instead of bottles or packets of amenities. It reused bath towels and bed covers, and avoided use of disposable packages (e.g. for jam, honey, butter) for breakfast. In order to save paper, guest reservations were only done electronically. Paper and cardboard were separated out for recycling, and packaging received was used to make gifts for employees. Rainwater was harvested to flush the toilets, to reduce consumption. They employed the standard ABNT 15401, as developed by the Brazilian Tourism Committee. Italy2 noted that they employed ISO 9001 to certify their services, supplies were bought by the parent company with they as a business unit ordering only what was required, and staff sought to minimise the printing of documents. However, these measures were undertaken 'locally', as the parent company did not have an environmental policy, and environmental sustainability was not an item built into their strategic focus.

However, there were some UK organisations that made mention of upstream initiatives. For example, UK12 stated that "our whole business is based on conservation, reuse, up-cycling and 
having a low carbon footprint". The company used a biofuel heating system, and conserved water. Food served was locally sourced, and the menus designed to reduce waste. Packaging was minimised through the supply chain, with any that was produced being recycled. The company's aim was to "sell nothing that is imported, new, etc., unless it is locally crafted or perused." While UK11 stated that they ordered supplies as and when necessary. The restaurant also noted that they tried to keep portion sizes down in order to reduce waste.

\subsubsection{Did environmental regulations cause a negative or positive impact?}

While some UK companies argued that regulations had a negative influence on their business, particularly along the supply chain, none from the other three countries expressed any such concerns. For example, even though UK14 made mention of the positives, they also argued that legislation had had a negative impact. The company noted that previously it had moved from a phase where they could "accumulate machines and sell them for scrap metal", through not being able to get the rid of the old machines, to now being "at the point of having to pay for someone to get the rid of them". The company also noted that the financial costs of being a part of the Waste Electrical and Electronic Equipment (WEEE) compliance scheme - a UK scheme to ensure that electrical and electronic waste is effectively managed - for them as a small business, outweighed the benefits. UK4 stated that indirectly environmental legislation did not impact upon the business, "indirectly due to the added costs to other organisations some of the costs are passed on to us and therefore has a negative impact". Similarly, UK9 was of the view that "suppliers who the legislation affects have seen a rise in their operating costs, causing their prices to rise year on year".

Overall, most of the 15 interviewees were of the view that environmental regulations had a positive impact. For example, UK4 noted that they had started to charge for carrier bags since 
the introduction of the carrier bag levy. While UK11 argued that being more sustainable (i.e. conservation resources), "kept the costs down".

Brazil2 argued that smaller competitors:

"had more difficulties to comply with, therefore this creates business advantages for the companies that cares about the environment and disadvantages for new entrants. For example, bigger companies can dispose waste with one truck travel while small ones need to do several travels or administrate internally for longer time their waste, increasing the risk".

Both German companies stated that compliance with environmental regulations contributed to enhancing the public image of the company. For example, Germany2 stated that as "a global player, they simply need supply chain management, because of strategic reason and I think marketing reasons as well.

\section{Discussion}

\subsection{Links at the country level}

The findings suggest that there is a relationship between environmental regulations, and competitiveness. However, the influence of the regulations varied within and between countries. For example, GHG emissions generally fell across the three European countries, but rose in Brazil (Fig. 5). Similarly to Colyer (2004), despite there being similar environmental regulations across Europe, there was variation in competitiveness. It is possible that this difference may have been due to variation in implementation and enforcement of the regulations. Indeed, for example, there were significant differences in the nature of the relationship between the rise in environmental taxes and the development of environmental technologies, across the three countries. 
The relative GHG emissions levels between the four case study countries, would suggest that there was a link between emission levels and GDP. Indeed, Germany and the UK, with the strongest economies, had higher levels than Italy and Brazil. Thus similarly to previous studies, there did appear to be a link between pollution control and development, and indeed the state of the country's economy (WCED, 1987; Shafik and Bandyopadhyay, 1992; Grossman and Kreuger, 1995; Esty and Porter, 2005). In the case of Italy, for example, which has struggled economically, this could account for the lower investment in pollution abatement technologies (Fig. 2). In addition, in Brazil, with its vast and varied terrain, and therefore difficulty with respect to access to resources, as well as effective implementation, might explain the low development of patents (Fig. 3). Germany was by far the highest producer of environmental patents (Fig. 3). This seeming 'dichotomy' of higher levels of emissions and patents, is most likely due to increased productivity and innovation linked to the rising German economy during the period of study. While the lower number of environmental patents in Brazil may simply be a reflection of the fact that even though environmental regulations have increased in the country, and are covering a wider range of factors, the size and differences in development, make technology uptake slower than in Europe. Differences in trade between countries may have also had an influence, however, this issue would require a more detailed study.

Across the EU, the majority of the increase in expenditure has been on the least developed countries such as Latvia, Lithuania, Romania, Slovakia and Poland, based in part on the Europe 2020 Strategy (EC, 2010). Even though per capita spend in Italy was 'high', overall (Fig. 1), it was in Germany and the UK that the highest overall investment has been made in environmental protection (Fig. 2). Indeed, innovation as measured by gross domestic expenditure on research and development (GERD), as a percentage of GDP, was by far highest in Germany at 2.94, followed by the UK at 1.63 and Italy at 1.25 (EC, 2015). The rise in the 
development of environmental technologies in Brazil may have been as a result of the introduction of the federal legislation in the late 1990s and early $2000 \mathrm{~s}$.

\subsection{Links at the sector and organisational levels}

Similarly to at the country level, the findings suggest that there was a relationship between competitiveness, and sectors and organisations (WBCSD, 2005; Koch, 2015). However, the relationship varied between countries and sectors (Table 2). For example, levels of innovation (as measured by the development of patents was highest in Germany. While the development of environmental technologies was higher in the manufacturing and construction sectors, as opposed to the energy sector. The impact of environmental taxes varied. The higher impacts on the manufacturing and construction sectors, particularly for the UK and Italy may simply reflect that the energy sector was already implementing conservation initiatives, and also that there was a higher starting point for Germany. It may also be that Germany had in place other policy measures and incentives, in addition to taxation to effect change. Nevertheless, as was the case in previous studies, the type of industry did appear to have an influence (Wubben, 1998; ShellSpringboard, 2006).

As illustrated in the interviews with the SMEs (which generally make up the largest percentage of businesses), the relative costs of environmental regulation are generally marginal compared to other costs (e.g. salaries and wages, interest rates). Therefore the link was not perceived to be a major one. Interestingly, however, some, particularly from the UK did make mention of the indirect impacts through for example, the passing on of costs through their supply chain, as well as the costs of being in waste management compliance schemes. For the SMEs, while in some cases there was an acknowledgement that if they conserved resources it reduced upon their costs, the perception wasn't strong enough to make resource conservation a strategic focus. Presumably, the thinking was that the environment wasn't a significant cost and any 
returns would be too low to be worth the effort. While the (perceived) impacts for SMEs may be less, the issue comes if or when they attempt to expand and potentially also to export. It is at this point that compliance with the regulations with other regions within their country or indeed other countries can result in them having to adapt and innovate in order to gain market share (ShellSpringboard, 2006).

The translation of the strength of the relationship at the national level, to the sector and organisational levels was mixed. For example, the German case study companies demonstrated a strong embedding of environmental regulations into their practices. Similarly, in Italy the lower strength of the relationship at the national level was also reflected at the sector and organisational levels. Indeed, within the Italian companies, the environmental measures that were being undertaken were due in large measure to specific senior managers within the organisations and not national or regional legislation. Alternatively, despite the lower national influence of environmental regulations, the Brazilian companies all demonstrated strong embedding of sustainable resource management within their strategic focus. It's important to note here though that in the case of Germany, the companies were from more polluting and energy intensive sectors, and thus the nature of the sector may thus have had a stronger influence than the country. The nature of the organisations may also have been an influencing factor, as it would be expected that it is those companies which are more engaged in sustainable practices that would be more likely to agree to participate in a survey such as this. Nevertheless, there did appear to be some support for the assertion that environmental regulations can boost organisational productivity (Jaffe et al., 1995).

The mix in the strength of the link between regulation and sector competitiveness can be explained in a number of ways. For example, as argued by Jaffe et al. (1995) it is only for companies operating in heavy polluting industries, that the costs of compliance are a significant fraction of the overall operational costs. In addition, as contended by Meyer (1992), businesses 
learn from trends in policy and adjust and innovate. Thus even though regulations may have increased, the availability of pollution abatement technologies and the percentage spend, particularly in Europe, has increased and therefore moderated the capital costs and therefore reduced the negative impacts. In addition, businesses have anticipated the abatement costs and have therefore built them into their planning. Indeed, unlike the more 'significant' spend on 'end of pipe' installations as was the case when regulations first came in, the costs for process change and product reformulation are closely aligned with general capital and operating spend, thus making them more difficult to disaggregate. Thus it is possible that the influence of the regulations though in existence, might very well be 'moderated'.

\section{Conclusions}

Ensuring economic development and competitiveness are aspirations of all countries and organisations. The principles of sustainable development, however, propose that economic progress should not be at the expense of social development or result in environmental degradation. Based on the findings from this study, these three issues can co-exist and are interrelated. However, the nature of the relationship is complex, with other factors (e.g. approaches to implementing environmental regulations, and the strategic focus of companies and their managers), also playing a role. The higher levels of regulation, coupled with higher innovation in Germany as compared to Brazil, would appear to suggest that regulations might be used as a mechanism to stimulate innovation (Porter, 1991; Dechezlepretre and Sata, 2014). Indeed, the links seen between high intensity sectors such as energy and manufacturing, and innovation, would appear to confirm the notion that regulations can act as a trigger for innovation. However, the nature of the relationship is complex and varies between and within countries and sectors. It is mediated by a number of factors, including for example, trade and government policies. Nevertheless, the results suggest that if environmental regulations are well thought through and targeted, they can result not only higher levels of innovation and by 
extension competitiveness at both the national and sectoral level, but also reducing the environmental impacts of processes and outputs. 


\section{References}

Andersen, M.S., et al. (2007) Competitiveness effects of environmental tax reforms (COMETR): publishable report to the European Commission. http://www2.dmu.dk/cometr/ (Accessed 22 January 2016).

Araújo, RS., Alves M.G., de Melo, M.T.C., Chrispin, Z.M.P., Mendes, M.P. and Júnior, G.C.S. (2015) 'Water resource management: a comparative evaluation of Brazil, Rio de Janeiro, the European Union and Portugal'. Science of the Total Environment Vol 511, pp 815 - 828.

Arouri, M., Caporale, G.M., Rault, C., Sova, R. and Sova, A. (2012) Environmental regulation and competitiveness: evidence from Romania. CESifo Working Paper 3916. www.cesifo.org/wp (Accessed 10 November 2015)

Carson, R. (1962). Silent spring. Penguin Modern Classics. NY. USA

Colyer, D. (2004). Environmental regulations and competitiveness. Working paper 2004-1. West Virginia University. West Virginia. USA.

Dechezlepretre, A. and Sato, M. (2014) The impacts of environmental regulations on competitiveness. Policy brief. Grantham Research Institute on Climate and the Environment: LSE. Global Green Growth Institute. London and Seoul.

De Santis, R. (2012) 'Impact of environmental regulations on trade in the main EU countries: conflict or synergy'? The World Economy Vol 35 No. (7), pp 799 - 815.

EC (European Commission) (2016) Circular economy strategy. http://ec.europa.eu/environment/circular-economy/index_en.htm (Accessed 23 January 2017) EC (European $\quad$ Commission) $\quad$ (2010) 2020. http://ec.europa.eu/europe2020/index_en.htm (Accessed 11 November 2015) 
EC (European Commission) (2015). Europe 2020 in your country: progress towards 2020 targets. http://ec.europa.eu/europe2020/index_en.htm (Accessed 10 November 2015)

EEA (European Environment Agency) (2015) More from less - material resource efficiency in Europe. http://www.eea.europa.eu/themes/economy/resource-efficiency (Accessed 20 January 2017)

Esty, D.C. and Porter, M.E. (2005) National environmental performance: an empirical analysis of policy results and determinants. Yale Law School. Faculty Scholarship Series. Paper 430.

Flick, U. (2014). An introduction to qualitative research. Sage Publications Ltd. London.

Gradient Corp (nd). Brazil environmental regulation increasing. http://gradientcorp.com/alerts/finals/Brazil.html (Accessed 14 September 2015)

Grossman, G.M. and Krueger, A.B. (1995) 'Economic growth and the environment', Quarterly Journal of Economics Vol 110, pp 353 - 377.

Harris, M.A., Konya, L. and Matyas, L. (2002) 'Modelling the impact of environmental regulations on bi lateral trade flows in the OECD 1990 - 1996', The World Economy Vol 25, No. 3, pp 387 - 405

Jaffe, A.B., Peterson, S.R., Portney, P.R and Stavins, R.N. (1995) 'Environmental regulation and the competitiveness of US manufacturing: what does the evidence tell us'? Journal of Economic Literature Vol XXXIII, pp 132 - 163.

Koch, G. (2015) Coca Cola water funds partnership investing directly in water resource management. http://www.coca-cola.co.uk/packages/sustainability/water-funds-partnershipinvesting-directly-in-water-resource-management/ (Accessed on 12 November 2015) 
Metcalfe, M.R. (2002) 'Environmental regulations and implications for competitiveness in international pork trade', Journal of Agriculture and Resource Economics, Vol 27 No. 1, pp. $222-243$.

Meyer, S.M. (1992) The economic impact of environmental regulations. http://web.mit.edu/polisci/mpepp/Reports/Econ\%20Impact\%20Enviro\%20Reg.pdf (Accessed 12 November 2015)

OECD (Organization for Economic Cooperation and Development) (2015a) Greenhouse gas emissions. http://stats.oecd.org/viewhtml.aspx?datasetcode=AIR_GHG\&lang=en (Accessed 5 October 2015)

OECD (Organization for Economic Cooperation and Development) (2015b) Green growth. Available at: http://stats.oecd.org/viewhtml.aspx?datasetcode=GREEN_GROWTH\&lang=en (Accessed 5 October 2015)

OECD (Organization for Economic Cooperation and Development) (2015c) OECD Stat. Technology development. http://stats.oecd.org/viewhtml.aspx?datasetcode=PAT_DEV\&lang=en (Accessed 5 October 2015)

OECD (Organization for Economic Cooperation and Development) (2015d) Expenditure and $\begin{array}{lll}\text { revenue, } & \text { investment } & \text { and }\end{array}$ http://stats.oecd.org/viewhtml.aspx?datasetcode=EPER\&lang=en (Accessed 5 October 2015) OECD (Organization for Economic Cooperation and Development) (2015e) Tax revenue. http://stats.oecd.org/viewhtml.aspx?datasetcode=ENV ENVPOLICY\&lang=en (Accessed 5 October 2015) 
OECD (Organization for Economic Cooperation and Development) (2015f) Employment by activity. Available at: https://data.oecd.org/emp/employment-by-activity.htm (Accessed 6 November 2015)

OECD (Organization for Economic Cooperation and Development) (2017). Real GDP forecast. https://data.oecd.org/gdp/real-gdp-forecast.htm (Accessed 25 February 2017)

Porter, M.E. (1991) America's green strategy. Scientific American, Vol 264, No. 4, pp. 168

Porter, M.E. and van de Linde, C. (1995a) 'Green and competitive: ending the stalemate. Harvard Business Review', pp. $120-134$.

Porter, M.E. and van de Linde, C. (1995b) 'Toward a new conception of the environmentcompetitiveness perspective', Journal of Economic Perspectives, Vol 9, pp. 97 - 118.

Porter, M.E. (1998). The competitive advantage of nations. Free Press. New York. USA.

Porter, M.E. and van de Linde, C. (2002). 'Toward a new conception of the environmentcompetitiveness relationship', in Gallagher, S.P., Werksman, J. (Eds.). The Earthscan Reader on International Trade and Sustainable Development. Earthscan Publications Ltd. London.

ShellSpringboard (2006) Opportunities for innovation: the business opportunities for SMEs in tackling the causes of climate change. http://www.vivideconomics.com/wpcontent/uploads/2006/10/Vivid_Econ_SME_Opportunities.pdf (accessed on November 6, 2015)

Smith, A.D. and Rupp, WT. (2002) 'Application service providers (ASP): moving downstream to enhance competitive advantage,' Information Management \& Computer Security, Vol. 10, No. 2, pp. $64-72$. 
Statista (2017) Global inflation rate. https://www.statista.com/statistics/256598/globalinflation-rate-compared-to-previous-year/ (Accessed 27 February 2017)

Tobey, JA. (1990) 'The effects of domestic environmental policies on patterns of world trade: an empirical test,' Kyklos Vol. 43, No. 2, pp. 191 - 209

Triebswetter, U. and Hitchens, D. (2005) 'The impact of environmental regulation on competitiveness in the German manufacturing industry - a comparison with other countries in the European Union,' Journal of Cleaner Production Vol. 13, pp. 733 - 745

UNEP (United Nations Environmental Programme) (2017) UNEP's resource efficiency programme.

http://www.unep.org/resourceefficiency/Home/UNEPsResourceEfficiencyProgramme/tabid/5 5552/Default.aspx (Accessed 20 January 2017)

WBCSD (World Business Council for Sustainable Development) (2005) Beyond reporting: creating business value and accountability. Geneva: Switzerland.

WCED (World Commission on Environment and Development) (1987) Our common future. Oxford. University Press. Oxford.

World Bank (2015) World development indicators. http://databank.worldbank.org/data/reports.aspx?source=2\&Topic=6 (Accessed 5 November 2015)

World Bank (2016) Global economic prospects: divergences and risks. https://openknowledge.worldbank.org/bitstream/handle/10986/24319/9781464807770.pdf?se quence $=6$ (Accessed 20 January 2017) 
Wubben, M. (1998) 'What's in it for us? Or: the impact of environmental legislation on competitiveness,' Business Strategy and the Environment Vol. 8, pp. 95 - 107. 
Table 1: The countries and sectors with whom interviews were conducted

\begin{tabular}{|c|c|c|c|c|c|c|c|c|}
\hline & UK & & Italy & & Germany & & Brazil & \\
\hline & Sector & Size & Sector & Size & Sector & Size & Sector & Size \\
\hline 1 & Services - laundrette & SME - local & $\begin{array}{l}\text { Services - } \\
\text { waste } \\
\text { management }\end{array}$ & $\begin{array}{l}\text { SME - } \\
\text { international }\end{array}$ & $\begin{array}{l}\text { Automotive } \\
\text { supplier }\end{array}$ & $\begin{array}{l}\text { Large - } \\
\text { international }\end{array}$ & Food & $\begin{array}{l}\text { Large - } \\
\text { international }\end{array}$ \\
\hline 2 & Services - laundrette & SME - local & Healthcare & Large - regional & Manufacturing & $\begin{array}{l}\text { Large - } \\
\text { international }\end{array}$ & Farm & Large - regional \\
\hline 3 & Retail - DIY & SME - local & Services $-\mathrm{NGO}$ & $\begin{array}{l}\text { Large - } \\
\text { international }\end{array}$ & & & Hotel & Large - national \\
\hline 4 & Retail - corner shop & SME - local & $\begin{array}{l}\text { Services - } \\
\text { waste } \\
\text { management }\end{array}$ & SME - regional & & & $\begin{array}{l}\text { Financial } \\
\text { services }\end{array}$ & Large - national \\
\hline 5 & $\begin{array}{l}\text { Services - electronics } \\
\text { repair }\end{array}$ & SME - local & & & & & & \\
\hline 6 & $\begin{array}{l}\text { Services - facilities } \\
\text { management }\end{array}$ & Large - national & & & & & & \\
\hline 7 & Retail - florist & SME - local & & & & & & \\
\hline 8 & Retail - plumbing & SME - local & & & & & & \\
\hline 9 & $\begin{array}{l}\text { Retail - sports } \\
\text { equipment }\end{array}$ & SME - local & & & & & & \\
\hline 10 & $\begin{array}{l}\text { Retail - used } \\
\text { furniture }\end{array}$ & SME - national & & & & & & \\
\hline 11 & Retail - restaurant & SME - local & & & & & & \\
\hline 12 & Retail - used clothes & SME - local & & & & & & \\
\hline 13 & $\begin{array}{l}\text { Retail - gifts/artists' } \\
\text { supplies }\end{array}$ & SME - local & & & & & & \\
\hline 14 & $\begin{array}{l}\text { Retail - sewing } \\
\text { machines }\end{array}$ & SME - local & & & & & & \\
\hline
\end{tabular}


Table 2: Comparison of correlation between GHG emissions in the three EU countries and selected innovation factors

\begin{tabular}{|l|l|l|l|l|l|l|}
\hline & \multicolumn{2}{|l|}{ GHG emissions in Italy } & \multicolumn{2}{l|}{ GHG emissions in the UK } & \multicolumn{2}{l|}{$\begin{array}{l}\text { GHG emissions in } \\
\text { Germany }\end{array}$} \\
\hline & $\begin{array}{l}\text { In the } \\
\text { energy } \\
\text { sector }\end{array}$ & $\begin{array}{l}\text { In the } \\
\text { manufacturing } \\
\text { and } \\
\text { construction } \\
\text { sectors }\end{array}$ & $\begin{array}{l}\text { In the } \\
\text { energy } \\
\text { sector }\end{array}$ & $\begin{array}{l}\text { In the } \\
\text { manufacturing } \\
\text { and } \\
\text { construction } \\
\text { sectors }\end{array}$ & $\begin{array}{l}\text { In the } \\
\text { energy } \\
\text { sector }\end{array}$ & $\begin{array}{l}\text { In the } \\
\text { manufacturing } \\
\text { and } \\
\text { construction } \\
\text { sectors }\end{array}$ \\
\hline $\begin{array}{l}\text { Development of } \\
\text { technology } \\
\text { patents }\end{array}$ & 0.50 & -0.32 & -0.51 & -0.45 & -0.76 & -0.91 \\
\hline $\begin{array}{l}\text { Development of } \\
\text { environmental } \\
\text { technologies }\end{array}$ & -0.33 & -0.96 & -0.55 & -0.95 & -0.59 & -0.51 \\
\hline $\begin{array}{l}\text { Rise in } \\
\text { environmental } \\
\text { taxes }\end{array}$ & -0.14 & 0.49 & -0.21 & 0.56 & 0.28 & -0.29 \\
\hline
\end{tabular}




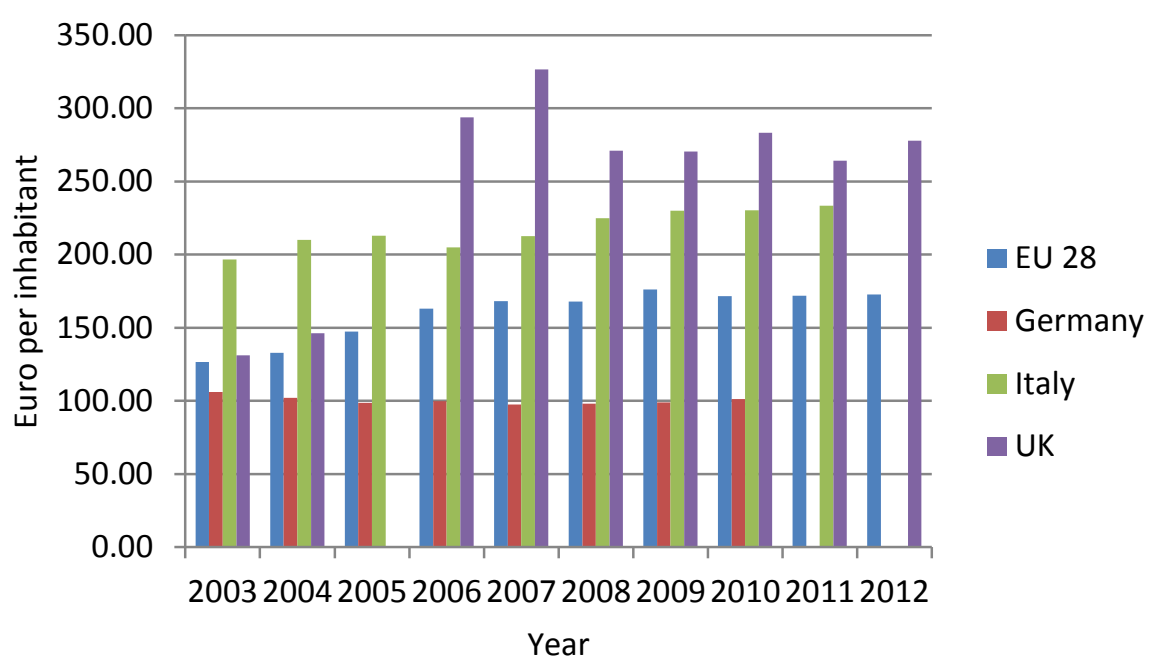

Fig. 1: Per capita spend on environmental protection in the selected countries compared to the $\mathbf{E U} 28$ countries

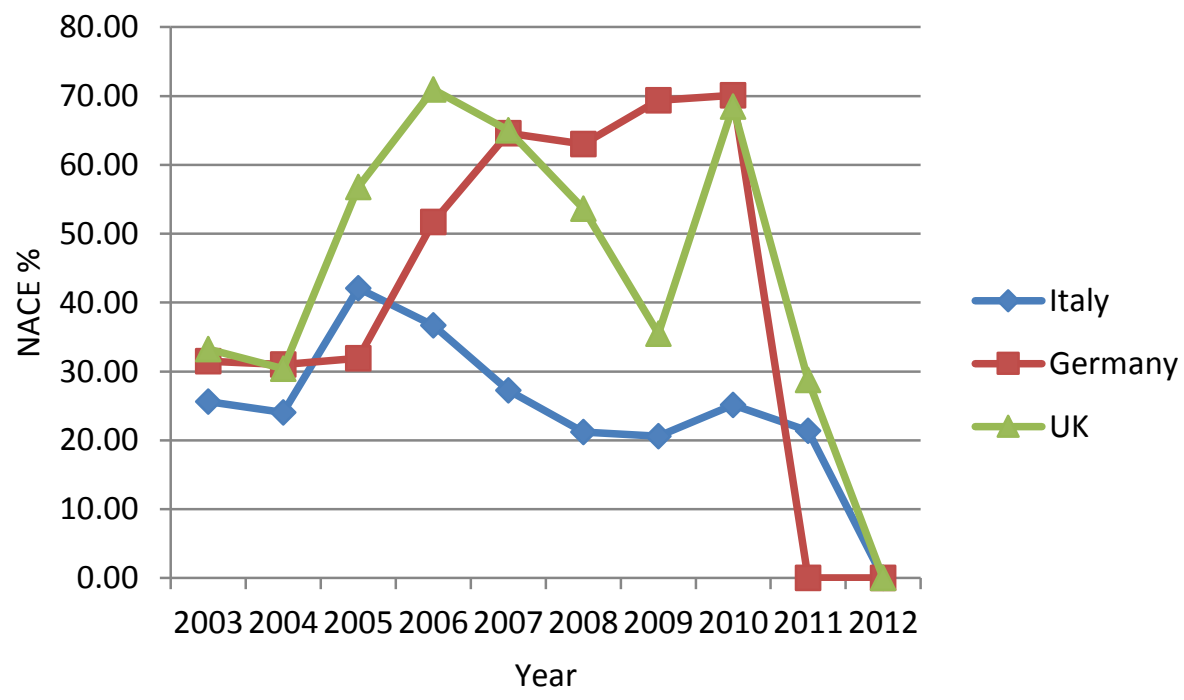

Fig. 2: Pollution prevention protection as a \% of total environmental protection investment in the selected countries 


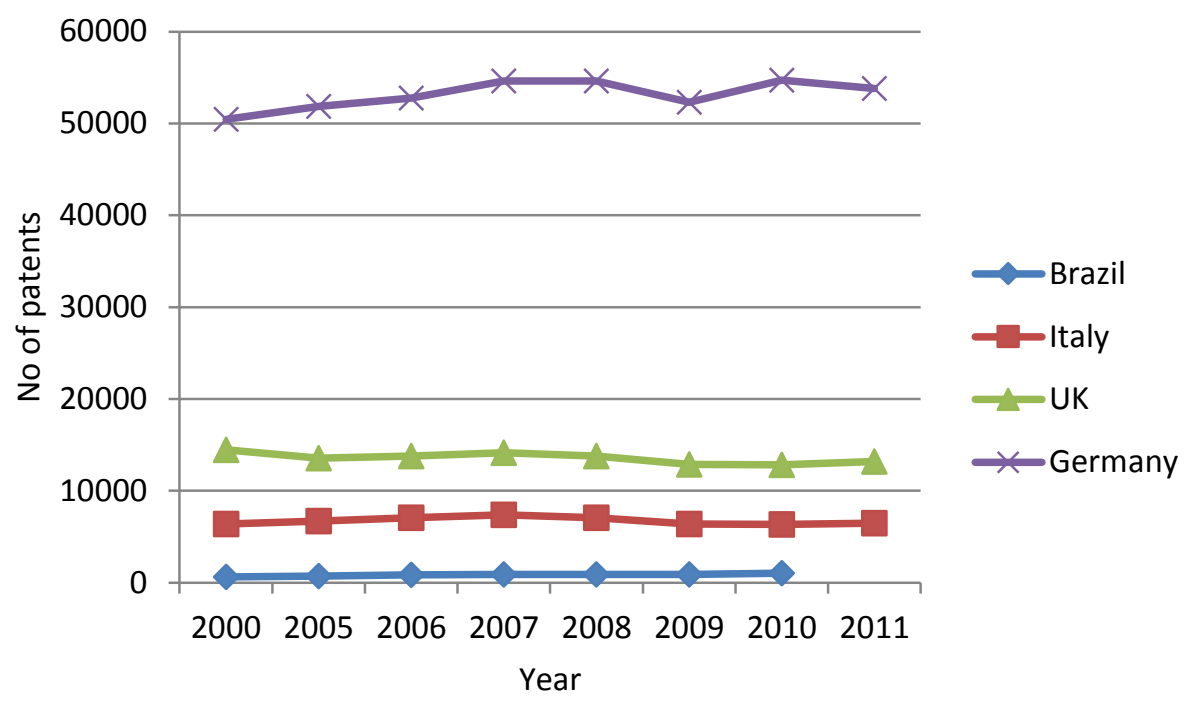

Fig. 3: Comparison of development of patents for environmental technologies, between the four case study countries from 2000 - 2011

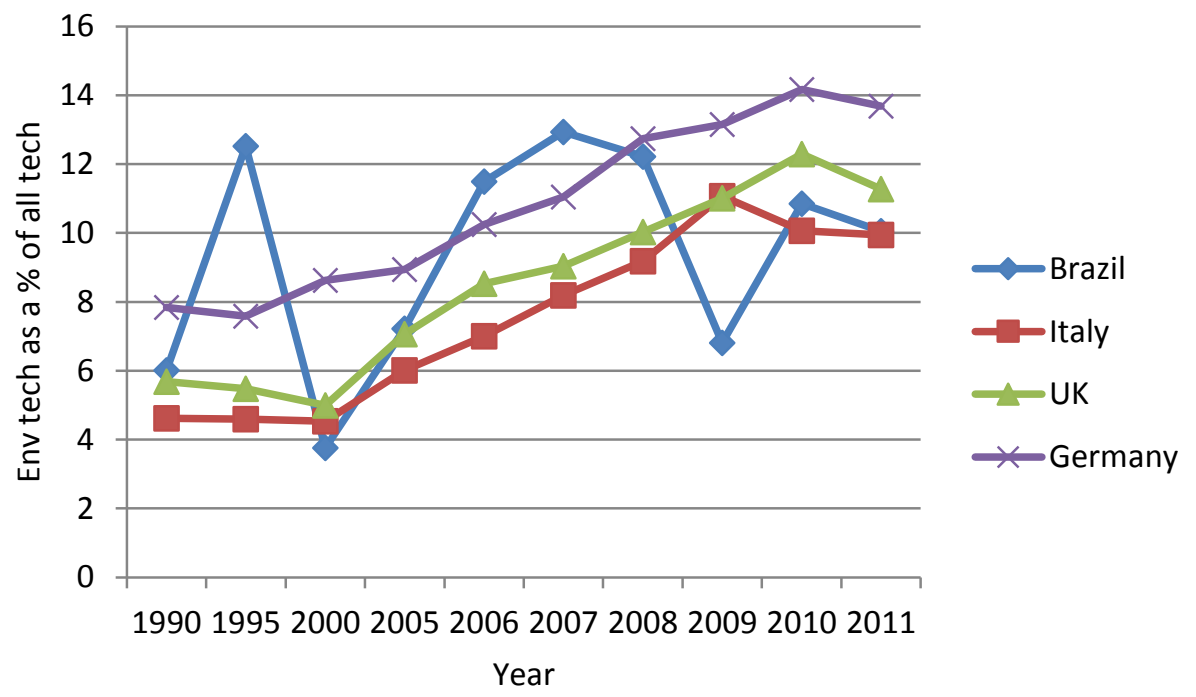

Fig. 4: Comparison of the development of environmental technologies as a percentage of all technologies, in the four case study countries, from 1990 - 2011 


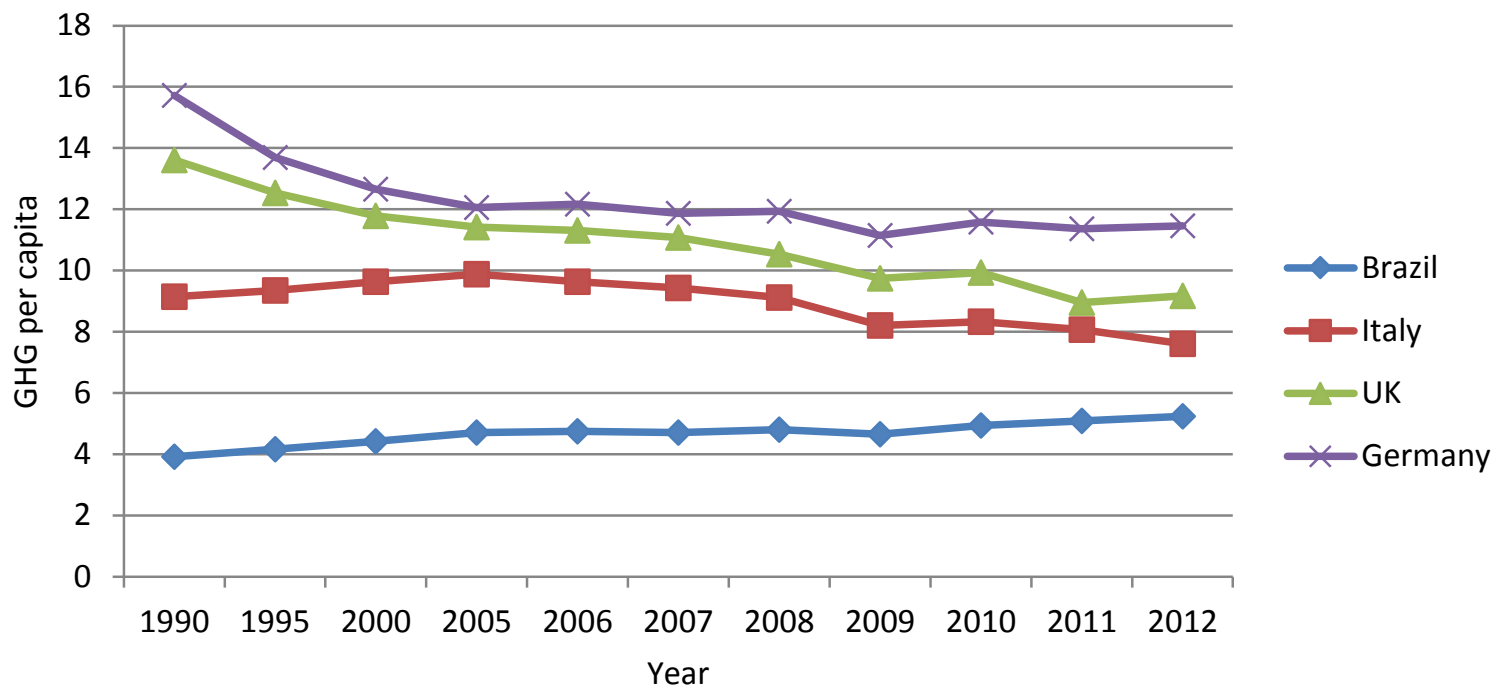

Fig. 5: Comparison of GHG emissions for the four selected countries between 1990 2012 